\title{
DETERMINAN TINGKAT BAGI HASIL DEPOSITO MUDHARABAH PERBANKAN SYARIAH DI INDONESIA ${ }^{1}$
}

\author{
Huzein Satrio Prasetyawan \\ Departemen Ekonomi Syariah-Fakultas Ekonomi dan Bisnis-Universitas Airlangga \\ Email: huzein.satrio.prasetyawan-2015@feb.unair.ac.id \\ Imron Mawardi \\ Departemen Ekonomi Syariah-Fakultas Ekonomi dan Bisnis-Universitas Airlangga \\ Email: ronmawardi@feb.unair.ac.id
}

\begin{abstract}
:
The purpose of this research is to analyze the effect of Return On Assets, SBIS, IPI, and Exchange Rate toward the rate of return mudharabah deposits islamic bank industries in Indonesia start from January 2012 until December 2017. This research use quantitative approach. The analysis method used in this research is Vector Error Correction Model. This research used saturation sampling, the data in this study are secondary data obtained from OJK, BI, and BPS. The results showed that Return On Assets, IPI, and Exchange Rate have a significant effect on the profit sharing rate of mudharabah deposits in the long term and have no significant effect in the short term. While the SBIS variable does not significantly influence the level of profit sharing of mudharabah deposits in the long and short term. Then the biggest influence that influenced the development of Islamic banks in Indonesia in the 2012-2017 research period was the exchange rate.

Keywords: Islamic Banking, ROA, SBIS, IPI, Exchange Rate, Rate of Return Deposito Mudharabah, Vector Error Correction Model.
\end{abstract}

\section{PENDAHULUAN}

Lembaga keuangan memiliki peran yang penting dalam mengatur sirkulasi keuangan pada perekonomian suatu negara yaitu sebagai lembaga intermediasi dan penyedia jasa kevangan. Di Indonesia sendiri lembaga keuangan dibagi atas dua bentuk yaitu lembaga keuangan bank dan lembaga keuangan bukan bank. lembaga keuangan bank merupakan badan usaha yang melaksanakan kegiatan penghimpunan dana dari masyarakat dalam bentuk simpanan dan penyaluran dana kepada berbentuk kredit pembiayaan atau bentuk lainnya dengan tujuan untuk menaikkan taraf hidup masyarakat banyak (UU No 10 Tahun 1998 tentang Perbankan). Di Indonesia lembaga keuangan bank menganut dual banking system, karena itu lembaga keuangan bank di Indonesia terdiri atas bank konvensional dan bank syariah. Dalam menjalankan kegiatannya perbankan syariah berpegang teguh pada prinsip syariah yaitu menghilangkan maysir, gharar, riba, dzhalim, dan haram. Sebagai lembaga intermediasi, bank syariah tidak menggunakan sistem bunga dalam operasionalnya. Menurut Keputusan MUI Nomor 1 Tahun 2004 Tentang Bunga memutuskan bahwa bunga memberi karakteristik sama dengan riba sehingga hukumnya haram.

\footnotetext{
${ }^{1}$ Jurnal ini merupakan bagian dari skripsi dari Huzein Satrio Prasetyawan, NIM: 041511433108 , yang diuji pada 22 Oktober 2019.
} 
Sesuai dengan firman Allah dalam Surat Al - Baqarah ayat 275 :

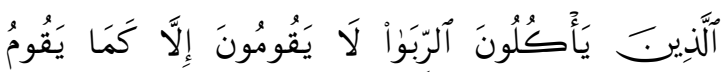

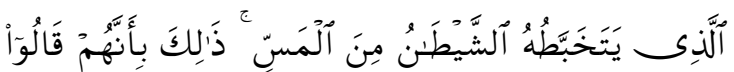

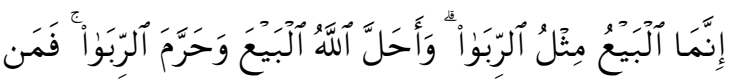

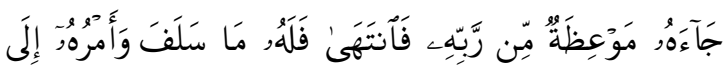

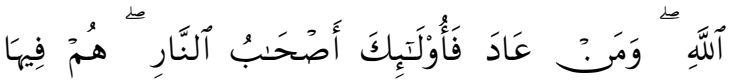

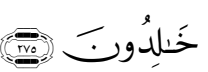

"Allażina ya kulụnar-ribā lā yaqụmụna illā kamā yaqụmullażī yatakhabbațuhusysyaițānu minal-mass, żālika bi annahum qālū innamal-bai'u miślur-ribā, wa ahallallāhul-bai'a wa harramar-ribā, fa man jā’ahụ mau'izatum mir rabbihī fantahā fa lahụ mā salaf, wa amruhū ilallāh, wa man 'āda fa ulă ìka aṣ-hābunnār, hum fịhā khālidụn"

Artinya: "Orang-orang yang memakan riba tidak dapat berdiri melainkan seperti berdirinya orang yang kemasukan setan karena gila. Yang demikian itu karena mereka berkata bahwa jual beli itu sama dengan riba. Padahal Allah telah menghalalkan jual beli dan mengharamkan riba. Barang siapa mendapat peringatan dari Tuhannya lalu dia berhenti, maka apa yang telah diperolehnya dahulu menjadi miliknya dan urusannya (terserah) kepada Allah. Barang siapa mengulangi, maka mereka itu penghuni neraka, mereka kekal di dalamnya." (Departemen Agama, 2012).

Menurut Karim (2014:97) produk pada perbankan syariah dibagi atas tiga bagian besar yaitu produk penyaluran dana (financing), penghimpunan dana (funding), dan jasa (service). Produk yang ditawarkan oleh perbankan syariah bertujuan untuk memenuhi kebutuhan nasabah yang sesuai dengan prinsip islam. Penghapusan system riba pada produk simpanan dalam bank syariah dan digantikan dengan system bagi hasil. Salah satu produk simpanan bank syariah yang ditawarkan adalah deposito berjangka dengan akad mudharabah.

Menurut Wiroso (2011:78) Bank syariah sebagai manajer investasi dari para shahibul mal (pemilik dana) harus berhati - hati, profesionalisme dan ahli dalam mengelola dana. Besar kecilnya bagi hasil yang diterima oleh pemilik dana tergantung dari pendapatan usaha yang diperoleh oleh bank syariah dalam mengelola dana. Faktor jumlah pendapatan dari bank syariah dengan pertimbangan adanya faktor - faktor lain mempengaruhi tingkat bagi hasil dari deposito mudharabah seperti faktor internal maupun eksternal. Tidak hanya membandingkan produk yang sama pada bank konvensional, bank syariah memperhatikan pula factor - factor makroekonomi maupun kinerja keuangan dari bank itu sendiri dalam menentukan bagi hasil nasabahnya.

\section{LANDASAN TEORI}

\section{Bank Syariah}

Dalam bidang perbankan syariah, tidak ditemukannya ayat atau lafaz dalam Al - Qur'an dan hadits yang menjelaskan tentang perbankan, 
melainkan akan menemui perintah tentang tata cara bermuamalah, yaitu seperti pengharaman riba, pelarangan berlaku zalim, transakasi bathil dan transaksi lainnya yang dilarang. Maka dari itu, penetapan tentang perbankan menggunakan konsep istilahi yakni konsep yang berasal dari pemikiran yang berdasar pada asas kemaslahatan yang diambil dari ayat - ayat Al - Qur'an dan hadist yang berisi tentang prinsip - prinsip maqashid syariah (Minhajuddin, 2004). Dari konsep itulah dibentuk sebuah lembaga yang dapat melindungi jiwa dan harta manusia dari hal yang diharamkan, zalim, dan hal - hal yang dilarang dalam agama.

Perbankan konvensional yang memakai system bunga dan hal yang dilarang oleh agama adalah awal lahirnya perbankan syariah. Menurut konsep yang telah dipaparkan diatas hadirnya bank syariah guna untuk melindungi jiwa dan harta manusia dari transaksi yang diharamkan. Bank syariah adalah sebuah lembaga kevangan yang dalam pokok usahanya yakni memberikan kredit dan jasa lain dalam transaksi pembayaran serta peredaran vang operasionalnya disesuaikan dengan prinsip islam (Anshori, 2018). Kredit pada bank syariah yang dimaksud adalah pembiayaan. Singkatnya, bank syariah adalah bank yang melalukan usahanya berdasarkan prinsip islam.

Di Indonesia sendiri peraturan pertama kali tentang perbankan syariah berlandaskan pada UU No. 7 Tahun 1992 yang selanjutnya dilakukan amandemen menjadi UU No. 10 tahun 1998. Hadirnya UU No. 10 tahun 1998 memberikan landasan hukum yang kuat bagi eksitensi dari bank syariah. Keberadaan dari bank syariah sendiri semakin mapan setelah dibentuknya peraturan khusus tentang bank syariah yaitu pada UU No. 21 Tahun 2008.

Menurut IAI (2002) Kegiatan dari bank syariah sendiri adalah implementasi dari prinsip - prinsip ekonomi islam dengan karakteristik sebagai berikut :

1. Pelarangan riba dalam berbagai bentuknya

2. Tidak mengenal konsep time value of money

3. Uang sebagai alat tukar bukan komoditas

4. Tidak diperkenankan melakukan kegiatan yang bersifat spekulatif

5. Tidak diperkenankan menggunakan dua harga untuk satu barang

6. Tidak diperkenankan dua transaksi dalam satu akad.

\section{Peran dan Kegiatan Bank Syariah}

Keberadaan bank syariah di Indonesia telah mendapatkan landasan hukum yang kuat setelah dikeluarkannya peraturan - peraturan tentang perbankan syariah dan bagi hasil yang dimana secara tegas diakui keberadaannya dan fungsinya sebagai Bank bagi hasil atau bank islam. Dengan itu, bank syariah adalah bank yang beroperasi dengan prinsip bagi hasil dan prinsip muamalah 
berdasarkan syariah dalam melakukan kegiatannya.

Menurut Muhammad (2014) bank syariah dalam menjalankan usahanya memiliki beberapa peran yaitu sebagai berikut :

1. Menjadi perekat nasionalisme baru, artinya bank syariah dapat menjadi fasilitator aktif bagi terbentunya jaringan usaha ekonomi kerakyatan.

2. Memberdayakan ekonomi umat dan beroperasi secara transparan

3. Memberikan return atau imbal hasil yang lebih baik kepada para investor atau nasabah.

4. Mendorong penurunan tingkat spekulasi di pasar keuangan.

5. Mendorong pemerataan pendapatan melalui pengumpulan dana ZIS (Zakat, Infaq, Shadaqah)

6. Peningkatan efisiensi mobilisasi dana dengan hadirnya produk almudharabah al-muqayyadah

7. Uswah hasanah implementasi moral dalam menjalankan usaha bank.

Bank syariah dalam menjalankan perannya tersebut, bank syariah harus menjalankan usahanya secara maksimal. Menurut IAI (2002) kegiatan dari bank syariah adalah sebagai berikut :

1. Manajer investasi yang mengelola investasi atas dana nasabah dengan digunakannya akad mudharabah.

2. Investor maupun nasabah yang menginvestasikan dan mempercayakan dana kepada bank syariah dengan menggunakan alat investasi yang sesuai prinsip syariah dan membagi hasil yang diperoleh sesuai nisbah yang disepakati bersama.

3. Penyedia jasa pembayaran seperti bank konvensional sepanjang tidak bertentangan dengan prinsip syariah.

4. Pengemban fungsi social yakni sebagai pengelola dana ZIS serta pinjaman kebajikan (Qardhul Hasan) sesuai dengan ketentuan yang berlaku.

\section{Perbedaan Bank Konvensional dan Bank} Syariah

Perbankan syariah tidak hanya sekedar bank dengan system bagi hasil, akan tetapi bank syariah sebagai lembaga keuangan juga dapat melaksanakan transaksi - transaksi kevangan lainnya yang tidak hanya dilakukan oleh bank konvensional. Khir dkk (2008) membuat daftar beberapa perbedaan antara perbankan konvensional dan perbankan syariah yaitu sebagai berikut ini :

1. Bank syariah, fungsi dan model usaha didasarkan pada hukum syariah. Bank harus memastikan bahwa semua kegiatan bisnis telah memenuhi hukum syariah. Sedangkan bank konvensional, Fungsi dan model usaha didasarkan pada prinsip - prinsip sekuler dan tidak didasarkan pada hukum atau pedoman agama apa pun.

2. Bank syariah, Bank syariah dibatasi untuk tidak terlibat dalam aktivitas ekonomi yang tidak memenuhi ketentuan syariah. Sedangkan bank 
konvensional tidak ada batasan dalam aktivitas ekonominya.

3. Bank syariah, bank harus mematuhi peraturan perudangan pemerintah dan ketentuan syariah. Sedangkan bank konvensional, Bank harus mematuhi peraturan perudangan pemerintah saja.

\section{Pengelolaan Bank Syariah}

Tidak sedikit masyarakat yang menganggap bahwa bagi hasil tidak ada bedanya dengan pemberian / pengambilan bunga sehingga mereka beranggapan bahwa bank syariah dengan bank konvensional sama saja yang membedakan hanya istilah saja.

Perbankan syariah memiliki batasan - batasan dalam menjalankan kegiatannya dengan dasar pada syariat islam sehingga bank syariah harus menerapkan prinsip - prinsip yang tidak bertentangan dengan syariat islam seperti riba (usury dan interest), gharar (uncertainty), dan maysir (speculative).

Perbankan syariah dalam menjalankan kegiatannya menggunakan prinsip - prinsip sebagai berikut :

1. Prinsip Jual Beli

2. Prinsip Al - Wadiah (titipan atau simpanan)

3. Prinsip Al - ljarah (sewa)

4. Prinsip Profit Sharing (bagi hasil)

5. Prinsip Fee-Based Service (jasa).

Produk Penghimpunan Dana Bank Syariah Penghimpunan dana pada bank merupakan jasa utama yang ditawarkan pada industry perbankan. Menurut
Muhammad Djumhana (1993:169) mengemukakan bahwa dana yang dihimpun oleh bank dari masyarakat merupakan unsur penting dari perbankan yang selanjutnya dikelola untuk mencari keuntungan.

Kegiatan usaha penghimpunan dana dari masyarakat tidak hanya dapat dilakukan oleh perbankan konvensioanl melainkan juga dapat dilakukan oleh perbankan syariah dengan menggunakan prinsip syariah. Penghimpunan dana dari masyarakat ini dapat dihimpun melalui dalam bentuk simpanan maupun investasi berupa giro, deposito berjangka, sertifikat deposito, dan dalam bentuk lain yang sama seperti itu. Dalam konteks perbankan syariah, peraturan tentang simpanan dan investasi telah diatur dalam Pasal 1 Ayat 20 Nomor 21 Tahun 2008. Penghimpunan dana berupa tabungan dan investasi ini menggunakan akad wadi'ah dan mudharabah.

\section{Deposito Mudharabah}

Masyarakat sebagai nasabah apabila memiliki kelebihan dana atau likuiditas dapat menempatkan dana pada instrument investasi jangka pendek yang ditawarkan oleh bank syariah yaitu deposito mudharabah. Disebut sebagai wadah investasi bagi nasabah dikarenakan adanya bagi hasil atas investasi dana nasabah yang dilakukan oleh perbankan ke sector produktif. Menurut pasal 1 ayat 22 UU Nomor 21 Tahun 2008 menjelaskan bahwa deposito 
mudharabah adalah investasi dana berdasarkan akad mudharabah atau akad lain yang tidak bertentangan dengan prinsip syariah yang penarikannya hanya dapat dilakukan pada waktu tertentu berdasarkan akad antara nasabah penyimpan dan bank syariah dan atau UUS. Jangka waktu deposito baik di bank syariah dan bank konvensional adalah 1 bulan, 3 bulan, dan 6 bulan.

Dasar hukum deposito mudharabah telah diatur dalam peraturan sebagai berikut :

1. DSN MUI melalui fatwa Nomor 03/DSNMUI/IV/2000.

2. Pasal 5 Peraturan Bank Indonesia Nomor 7/46/PBI/2005.

3. Surat Edaran Bank Indonesia Nomor 10/14/DPbS Tanggal 17 Maret 2008.

4. UU Republik Indonesia Nomor 21 Tahun 2008.

\section{Jenis - jenis deposito}

Jika dilihat berdasarkan kewenangan yang diberikan oleh pemilik dana (shahibul maal) deposito mudharabah memiliki dua bentuk (Adhiwarman Karim, 2016) yaitu Mudharabah Mutlaqah (Unrestricted Investment Account, URIA) dan Mudharabah Muqayyadah (Restricted Invetment Account, RIA).

1. Mudharabah Muqayyadah

Rumus perhitungan bagi hasil deposito mudharabah mutlaqah (URIA) adalah sebagai berikut :

hari bagi hasi $\times$ nominal deposito mudharabah $\times$ tingkat bagi hasil hari kalender yang bersangkutan

2. Mudharabah Muqayyadah
Untuk perhitungan bagi hasil cluster pool of fund yaitu dengan menggunakan rumus berikut ini :

hari bagi hasil $\times$ nominal deposito muqayyadah (RIA) $\times$ tingkat bagi hasil hari kalender bulan bersangkutan

Rumus perhitungan bagi hasil yang dapat digunakan untuk metode specific project adalah sebagai berikut ini:

$\begin{gathered}\frac{\text { hari bagi hasil }}{\text { hari bagi hasil terakhir }} \\ \text { sampai bagi hasil berikutnya } \\ \text { Return Proyek }\end{gathered} \quad \begin{gathered}\text { nominal deposito } \\ \text { yominal proyek }\end{gathered} \times$

\section{Sertifikat Bank Indonesia Syariah}

Operasi pasar terbuka (OPT) yang dilakukan oleh Bank Indonesia (BI) adalah sebagai sarana pengendalian moneter dan pengelolaan dana bank syariah. Untuk dari itu, Bl selaku pengambil kebijakan moneter menerbitkan instrument pasar terbuka yaitu berupa surat berharga dengan prinsip syariah berjangka waktu pendek dengan buktinya disebut Sertifikat Bank Indonesia Syariah (SBIS).

Sertifikat Bank Indonesia Syariah adalah instrument pasar terbuka yang diterbitkan oleh Bank Indonesia (BI) dengan menggunakan akad ju'alah. Penerbitan SBIS dimaksud bertujuan sebagai salah satu cara untuk mengatasi kelebihan likuiditas dari bank syariah. SBIS diterbitkan sebagai pengganti Sertifikat Wadi'ah Bank Indonesia (SWBI). Penggantian ini dilakukan karena SWBI belum bisa berfungsi secara optimal dalam pengendalian likuiditas bank syariah dan pengendalian moneter. 
Menurut Shoimah (2017) menunjukkan bahwa Sertifikat Wadiah Bank Indonesia berpengaruh positif signifikan terhadap tabungan mudharabah Bank Muamalat Indonesia. Pendapat lain dari Husnelly (2003) menunjukkan bahwa SBI tidak berpengaruh signifikan terhadap tingkat bagi hasil deposito mudharabah.

\section{Landasan Hukum SBIS}

Penerbitan dan segala hal yang berkaitan dengan SBIS telah diatur dalam Peraturan Bank Indonesia No. 10/11/PBI/2008 tentang Sertifikat Bank Indonesia Syariah. Selain peraturan dari Bank Indonesia, untuk menyokong keberadaan SBIS maka Majelis Ulama Indonesia menerbitkan fatwa tentang SBIS akad ju'alah yaitu fatwa No 64/DSNMUI/XII/2007 tentang SBIS Ju'alah

\section{Return On Assets}

Tingkat profitabilitas perusahaan dapat diukur melalui rasio profitabilitas yang pada nantinya hasil dari pengukuran dapat dijadikan bahan evaluasi kinerja manajemen perusahaan tersebut (Kasmir, 2016:196).

Return On Assets (ROA) adalah salah satu rasio yang sering digunakan dalam sebuah penelitian untuk mengukur profitabilitas perbankan syariah. Bank Indonesia sebagai pembina dan pengawas perbankan nasional menganjurkan profitabilitas bank diukur dengan menggunakan Return On Assets (ROA) karena lebih mengutamakan tingkat profitabilitas suatu perbankan diukur dengan menggunakan asset yang dimana sebagian besar dananya berasal dari dana simpanan masyarakat (Dendawijaya, 2009:199).

Berdasarkan lampiran 1d. Surat Edaran Bank Indonesia No.6/23/DPNP besarnya nilai Return On Assets dapat dinilai dengan rumus sebagai berikut ini :

$$
\text { ROA }=\frac{\text { Laba Sebelum Pajak }}{\text { Rata }- \text { rata total aset }} \times 100 \%
$$

Hasil pengukuran Return On Assets (ROA) dapat menggambarkan tingkat kesehatan perbankan syariah. Peringkat nilai ROA berdasarkan lampiran 1c. Surat Edaran Bank Indonesia No. 9/24/DPbS Sistem Penilaian Tingkat Kesehatan Bank Umum Berdasarkan Syariah.

Menurut Diaw dan Mbow (2011) Return On Assets berpengaruh positif signifikan terhadap bagi hasil deposito mudharabah bank syariah.

\section{Produk Domestik Bruto}

Gross Domestic Product (GDP) atau Produk Domestik Bruto (PDB) adalah nilai barang dan jasa yang diproduksikan di dalam suatu negara dalam satu tahun tertentu (Sukirno, 2006:34).

Nilai Produk Domestik Bruto dapat dihitung melalui dua macam dasar harga sebagai berikut (Sukirno, 2006:36) :

1. PDB Nominal (dasar harga berlaku)

2. PDB Riil (dasar harga tetap)

Data Produk Domestik Bruto Indonesia yang didapatkan dari Badan Pusat Statistik berupa data triwulanan dan tahunan, untuk dari itu dalam penelitian ini menggunakan data Indeks Produksi Industri (IPI) sebagai representative dari 
PDB riil (dasar harga konstan). Indikator ekonomi yang digunakan untuk mengukur nilai output produksi riil dengan tahun dasar tertentu sehingga perubahan harga tidak diikutsertakan dalam perhitungannya. Dengan tidak tersedianya data PDB bulanan, maka IPI digunakan untuk proyeksi dari PDB.

Dalam penelitian Ardiansyah dan Lubis (2018) mengatakan bahwa Indeks Produksi Industri (IPI) berpengaruh signifikan terhadap tingkat bagi hasil deposito mudharabah.

\section{Nilai Tukar}

Menurut Greenwald (1982:430) nilai tukar (exchange rates) adalah harga pasar dari mata vang asing dalam harga mata vang domestic atau sebaliknya. Kurs mata vang dapat ditentukan oleh hubungan permintaan dan penawaran terhadap mata vang tersebut.

Menurut Arifin (2006:231) terjadinya depresiasi rupiah terhadap dollar AS akan berdampak pada profitabilitas bank. Selain itu, depresiasi/melemahnya nilai rupiah terhadap USD dapat menyebabkan capital outflow atau pelarian modal masyarakat keluar negeri karena jika dibandingkan dengan mata vang negara lain maka ekspektasi return investasi di Indonesia lebih rendah. Berdasarkan hal ini, perubahan nilai tukar rupiah terhadap USD dapat mempengaruhi pertumbuhan jumlah rekening maupun dana pihak ketiga di perbankan syariah Indonesia. Dengan menurunnya pertumbuhan jumlah rekening maupun dana pihak ketiga perbankan syariah juga akan berdampak terhadap penurunan margin bagi hasil deposito mudarabah.

Pendapat lain diungkapkan oleh Monjazeb dan Ramanzanpour E (2013) mengatakan bahwa nilai tukar berpengaruh positif terhadap return pembiayaan bank syariah. Return yang didapatkan oleh bank syariah ini mempengaruhi jumlah pendapatan dari bank syariah itu sendiri. Seiring dengan pendapatan dari bank syariah meningkat maka diikuti oleh jumlah atau tingkat bagi hasil nasabah meningkat pula. Dengan demikian, nilai tukar berpengaruh positif signifikan terhadap tingkat bagi hasil deposito mudharabah.

\section{Metode Penelitian}

\section{Pendekatan Penelitian}

Dalam penelitian ini, pendekatan yang digunakan adalah kuantitatif. Penelitian ini ingin melihat hubungan jangka pendek dan jangka panjang faktor - faktor internal dan eksternal yang mempengaruhi tingkat bagi hasil deposito mudharabah dengan metode VAR/VECM.

1. Return On Assets

"Return On Assets (ROA) adalah rasio profitabilitas yang menunjukkan perbandingan antara laba (sebelum pajak) dengan total asset bank. Rasio ini menggambarkan tingkat efisiensi pengelolaan asset yang dilakukan oleh bank yang bersangkutan (Slamet Riyadi, 2006:156)". Dapat disimpulkan 
bahwa ROA adalah rasio yang menunjukkan tingkat pengembalian terhadap assets sehingga akan menggambarkan keefisiennan dari suatu assets dari bank.

Data ROA pada penelitian ini diperoleh dari Statistik Perbankan Syariah (SPS) terbitan Otoritas Jasa Keuangan tahun 2012 - 2017 dengan jenis data dalam bentuk bulanan.

2. Sertifikat Bank Indonesia Syariah

Menurut Bank Indonesia, Sertifikat Bank Indonesia Syariah (SBIS) adalah surat berharga berdasarkan prinsip syariah berjangka waktu pendek dalam mata vang rupiah yang diterbitkan oleh Bank Indonesia. SBIS diterbitkan oleh Bank Indonesia merupakan salah satu instrumen pasar dengan prinsip syariah yang digunakan untuk mengendalikan keadaan moneter. SBIS telah diatur dalam peraturan Bank Indonesia Nomor 10/11/PBI tanggal 31 Maret 2008 tentang Sertifikat Bank Indonesia Syariah. SBIS diperoleh dari Bank Indonesia melalui website www.bi.go.id dan Statistik Perbankan Syariah (SPS) terbitan OJK tahun 2012 - 2017.

3. Gross Domestic Product (GDP)

Gross Domestic Product atau Produk Domestik Bruto menurut Mankiw (2007:17) adalah jumlah produk barang dan jasa yang dihasilkan suatu negara dalam satu tahun. Akumulatif jumlah produk berupa barang dan jasa dari suatu negara dalam setahun dapat mengindikasikan keadaan ekonomi dari negara tersebut. Indeks Produksi Industri (IPI) digunakan pada penelitian ini sebagai proksi dari GDP, hal ini disebabkan pada penelitian ini menggunakan data bulanan sedangkan GDP tidak terdapat data bulanan didapatkan melalui www.bps.go.id atau BPS.

4. Nilai Tukar

Nilai tukar (kurs) adalah harga dari mata vang suatu negara dalam mata vang negara lain. Sebagai contohnya adalah nilai tukar mata uang Rupiah (Rp) terhadap mata vang Yen (¥). Nilai tukar yang digunakan dalam penelitian ini adalah nilai tukar Rupiah (Rp) terhadap Dollar AS (USD). Data nilai tukar diperoleh dari website www.bi.go.id dengan periode bulanan pada tahun 2012 - 2017.

5. Tingkat Bagi Hasil Deposito Mudharabah

Tingkat Bagi Hasil Deposito Mudharabah adalah suatu tingkat imbalan hasil yang diberikan kepada nasabah atas deposito dengan menggunakan akad Mudharabah. Tingkat bagi hasil ini diperoleh dari Statistik Perbankan Syariah (SPS) yang diterbitkan oleh Otoritas Jasa Kevangan dengan periode bulanan pada tahun 2012 - 2017.

\section{Jenis dan Sumber Data}

Data yang digunakan dalam penelitian ini adalah data sekunder. Data sekunder dalam penelitian berupa Sertifikat Bank Indonesia Syariah, Return 
On Asset, Gross Domestic Product, dan Nilai Tukar. Data - data yang digunakan diperoleh dari Statitstik Perbankan Syariah (SPS) yang diterbitkan oleh Otoritas Jasa Kevangan dan dari website www.bi.go.id dengan data merupakan data time series bulanan periode $2012-2017$.

\section{Populasi dan Sampel}

Populasi dalam penelitian adalah subyek yang akan diteliti dengan memiliki karakteristik tertentu untuk kemudian ditarik kesimpulan atas populasi tersebut. Populasi dalam penelitian ini adalah Bank Umum Syariah (BUS) dan Unit Usaha Syariah (UUS) yang tercatat pada Statistik Perbankan Syariah (SPS) dengan periode pengamatan penelitian adalah tahun $2012-2017$.

Sampel yang digunakan dalam penelitian ini adalah teknik sampling jenuh. Sampel jenuh adalah teknik penentuan sampel dilakukan bila jumlah populasi relatif kecil bila sehingga semua anggota populasi sama dengan sampel (Sugiyono, 2015:68). Sample dalam penelitian ini adalah sama dengan populasinya, yaitu Bank Umum Syariah (BUS) dan Unit Usaha Syariah (UUS) yang tercatat pada Statistik Perbankan Syariah (SPS) dengan periode pengamatan penelitian adalah tahun $2012-2017$.

\section{Teknik Pengumpulan Data}

Pengumpulan data yang dilakukan dengan metode dokumenter. Metode ini merupakan cara pengumpulan data dengan bahan bahan atau materi data yang menjadi sumber. Data yang sudah terkumpul yaitu melalui akses www.bi.go.id, www.ojk.go.id, www.bps.go.id data diolah kembali oleh penulis dengan tabulasi dan diteliti secara kuantitatif.

\section{Teknik Analisis Data}

Teknik analisis yang digunakan dalam penelitian ini adalah VAR/VECM, model Vector Auto Regression (VAR) akan dikombinasikan dengan Vector Error Correction Model (VECM) yaitu koreksi kesalaham, selain menggunakan analisis VECM akan digunakan analisis impulse response function (IRF) dan variance decomposition (VD).

\section{HASIL DAN PEMBAHASAN}

1. Hasil Uji Stasioneritas (unit root test) Uji Stasioner yang dilakukan adalah Augmented Dickey Flluer (ADF). Pengujian yang dilakukan menunjukkan bahwa terdapat satu variabel yang stasioner pada level sehingga dilakukan pengujian stasioner pada tingkat first difference agar menjadi stasioner dan model yang akan digunakan valid.

2. Penentuan Lag Lenght Optimal

Penentuan lag lenght optimal menunjukkan bahwa lag optimal terjadi pada lag kedua dengan dilihat dari tanda *) paling banyak.

3. Uji Kointegrasi Johansen's

Uji ini melihat apakah nilai hasil trace Statistic maupun Max-Eigen Statistic lebih besar dari nilai critical value. Hasil dari pengujian ini menunjukkan bahwa 
terdapat kointegrasi pada variabel eksogen.

4. Uji Estimasi VECM

Hasil pengujian estimasi VECM menunjukkan bahwa variabel ROA, IPI, dan Nilai Tukar berpengaruh secara signifikan dalam jangka panjang, hal ini dibuktikan dari nilai t-statistik yang lebih besar dari nilai t-tabel. Sedangka untuk variabel SBIS tidak berpengaruh secara signifikan dalam jangka panjang dengan nilai t-statistik lebih kecil dari pada nilai t-tabel.

5. Uji Impulse Response

Hasil pengujian menujukkan bahwa pada periode pertama variabel tingkat bagi hasil deposito mudharabah tidak memberikan pengaruh terhadap variabel ROA, SBIS, IPI, dan Nilai Tukar. ROA memberikan respon tertinggi dengan respon negatif sebesar 0.017228 pada periode ke-3, selanjutnya untuk SBIS memberikan respon tertinggi dengan respon positif sebesar 0.073471 pada periode ke-4 dengan. Variabel IPI memberikan respon tertinggi dengan respon positif sebesar 0.008800 pada periode ke-8, selanjutnya untuk variabel nilai tukar memberikan kontribusi tertinggi dengan respon negatif sebesar 0.016387 pada periode ke-2.

\section{Uji Variance Decomposition}

Pengujian VD memberikan hasil bahwa variabel Nilai Tukar memberikan kontribusi terbesar yaitu sebesar $5.97 \%$ dan terus meningkat dari periode ke periodenya. Selanjutnya variabel ROA memberikan kontribusi sebesar $0.66 \%$ cenderung meningkat dari periode ke periodenya. Variabel SBIS memberikan kontribusi sebesar $2.02 \%$ dan cenderung menurun. Terakhir variabel IPI memberikan variabel $0.024 \%$ dan cenderung meningkat.

\section{SIMPULAN}

Berdasarkan hasil pengujian data dan pembahasan yang telah dilakukan tentang faktor - faktor yang mempengaruhi tingkat bagi hasil deposito mudharabah yaitu Return On Assets, Sertifikat Bank Indonesia Syariah, Indeks Produksi Industri, dan Nilai Tukar, maka kesimpulan dari penelitian ini adalah :

1. Berdasarkan hasil estimasi VECM menunjukkan bahwa variabel ROA, IPI, dan Nilai Tukar dalam jangka panjang berpengaruh secara signifikan terhadap tingkat bagi hasil deposito mudharabah tetapi untuk variabel SBIS tidak berpengaruh signifikan dalam jangka panjang.

2. Untuk pengujian jangka pendek menunjukkan bahwa seluruh variabel penelitian yaitu ROA, SBIS, IPI, dan Nilai Tukar tidak berpengaruh signifikan terhadap tingkat bagi hasil deposito mudharabah.

3. Berdasarkan hasil pengujian impulse response menunjukkan bahwa perubahan terhadap SBIS dan IPI direspon fluktuatif serta cenderung positif terhadap tingkat bagi hasil deposito mudharabah. Sedangkan 
perubahan terhadap ROA dan Nilai

Tukar direspon fluktuatif serta cenderung negatif terhadap tingkat bagi hasil deposito mudharabah.

4. Berdasarkan hasil pengujian variance decomposition dari ROA, SBIS, IPI, dan Nilai Tukar menunjukkan bahwa untuk variabel yang memiliki kontribusi terbesar dalam mempengaruhi perubahan variasi pada variabel tingkat bagi hasil deposito mudharabah adalah variabel Nilai Tukar, kemudian ROA, diikuti SBIS dan yang terkecil yaitu IPI.

\section{Saran}

Berdasarkan hasil dan pembahasan penelitian diatas, maka terdapat beberapa saran yang dapat diberikan yaitu adalah :

1. Perbankan syariah di Indonesia khususnya BUS dan UUS yang menjadi objek penelitian ini diharapkan untuk memperhatikan faktor - faktor yang mempengaruhi bagi hasil tidak hanya pada internal saja akan tetapi faktor eksternal juga perlu diperhatikan, sehingga tingkat bagi hasil yang diterima oleh nasabah maksimal dan sesuai aturan.

2. Bagi masyarakat dan calon investor yang mempunyai kelebihan dana dan ingin menempatkan dananya, bank syariah dapat menjadi pilihan untuk menginvestasikan dana. Hal ini disebabkan karena bank syariah memiliki keuntungan yang tidak dimiliki oleh bank konvensional yaitu, kejelasan atas investasi dana hanya pada sektor halal dan tidak terdapat unsur maysir, gharar, haram, dan riba. Selain itu, return yang didapatkan tidak berdasarkan riba atau bunga melainkan bagi hasil profit sharing.

Bagi penelitian selanjutnya yang ingin meneliti mengenai tingkat bagi hasi deposito mudharabah dapat menggunakan variabel selain yang digunakana pada penelitian ini seperti dari sisi internal bank yaitu BOPO, CAR, FDR, dan NPF serta pada sisi eksternal bank yang dapat digunakan yaitu Inflasi, SBI, Jumlah Uang Beredar dan faktor lainnya. Selain itu dapat menggunakan objek Bank Perkreditan Rakyat Syariah (BPRS) serta Bank Umum Syariah (BUS) secara individual seperti Bank Mandiri Syariah, Bank BNI Syariah, Bank Muamalat Indonesia dan lain sebagainya.

\section{DAFTAR PUSTAKA}

Anshori, A. G. (2018) Perbankan Syariah di Indonesia. Yogyakarta: UGM Press.

Bank Indonesia. 2004. Surat Edaran Bank Indonesia Nomor 6/23/DPNP. Jakarta : Bank Indonesia. . 2005. Peraturan Bank Indonesia Nomor 7/46/PBI/2005. Jakarta : Bank Indonesia. 2007. Surat Edaran Bank Indonesia Nomor 9/24/DPbS. Jakarta : Bank Indonesia. 2008. Peraturan Bank Indonesia Nomor 10/11/PBI/2008. Jakarta : Bank Indonesia. 2008. Peraturan Bank 
Indonesia Nomor 10/11/PBI/2008.

Jakarta : Bank Indonesia. 2008. Surat Edaran Bank Indonesia Nomor 10/14/DPbS. Jakarta : Bank Indonesia. 2008. Surat Edaran Bank Indonesia Nomor 10/16/DPM. Jakarta : Bank Indonesia.

Indonesia, I. A. (2002) Standar Akuntansi Kevangan. Jakarta: Salemba Empat.

Karim, A. (2004) Bank Islam Analisis Fiqih dan Keuangan. Jakarta: PT Raja Grafindo Persada.

Karim, A. (2014) Bank Islam Analisis Fiqih dan Kevangan. Jakarta: PT Raja Grafindo Persada.

Karim, A. (2016) Bank Islam Analisis Fiqih dan Keuangan. Jakarta: PT Raja Grafindo Persada.

M, M. and E, R. (2013) "The Effect of Economic Factors on The Efficiency of Mutual Funds in Iran Seyedeh
Javaneh Ahmadi Tulamy",

Technical Journal of Engineering and Applied Sciences, 3 No 15, pp. 1707-1711.

Muhammad (2005) Manajemen Bank Syariah. Yogyakarta: UPP AMP YKPN.

Muhammad, D. (1993) Hukum Perbankan di Indonesia. Bandung: PT Citra Aditya Bakti.

Undang - Undang Republik Indonesia Nomor 7 Tahun 1992 Tentang Perbankan.

Undang - Undang Republik Indonesia Nomor 10 Tahun 1998 Tentang Perbankan.

Undang - Undang Republik Indonesia Nomor 21 Tahun 2008 Tentang Perbankan.

Sugiyono. 2015. Metode Penelitian Pendidikan (Pendekatan Kuantitatif, Kualitatif dan R\&D). Penerbit CV. Alfabeta: Bandung. 